\title{
I 009 Myocardial injury following percutaneous coronary intervention in complex lesion: a cardiovascular magnetic resonance imaging and cardiac marker study
}

\author{
Didier Locca*, Chiara Bucciarelli-Ducci, Agata Grasso, Peter Barlis, \\ Rick Wage, Giuseppe Ferrante, Sanjay K Prasad, Dudley J Pennell and \\ Carlo Di Mario
}

Address: Royal Brompton Hospital, London, UK

* Corresponding author

from I th Annual SCMR Scientific Sessions

Los Angeles, CA, USA. I-3 February 2008

Published: 22 October 2008

Journal of Cardiovascular Magnetic Resonance 2008, I0(SuppI I):AI34 doi:I0.I I86/I532-429X-I0-SI-AI34

This abstract is available from: http://jcmr-online.com/content/I0/SI/AI34

(c) 2008 Locca et al; licensee BioMed Central Ltd.

\section{Introduction}

In patients undergoing percutaneous coronary intervention (PCI), 15 to $26 \%$ develop elevated creatine kinase isoenzyme $\mathrm{MB}(\mathrm{CKMB})$ levels after the procedure. Troponin rise is even more frequent and is observed in 29$48 \%$ of patients in a standard daily practice procedure. Little is known about the mechanism of this damage specifically in patient with complex PCI. Cardiovascular Magnetic Resonance (CMR) with gadolinium-based contrast media administration can non-invasively detect myocardial fibrosis. Inversion recovery preparation with segmented gradient echo readout (GRE) using recovery sequences is considered the gold standard sequence for the detection of late gadolinium myocardial enhancement (LGE).

\section{Purpose}

Aim of this study was the correlation of pre- and post-procedural changes in cardiac enzymes and extent of initial/ post procedural areas of LGE measured by CMR in complex lesion.

\section{Methods}

Patients admitted to the hospital for PCI, stable/unstable angina or silent ischemia were enrolled. Only patients with complex coronary lesions are included. LGE CMR scan was performed 24 hours pre- and 24 hours post-PCI.
The amount of enhancement was quantified by planimetry based on signal intensity ( $>2 \mathrm{SD}$ ) of surrounding nulled myocardium.

\section{Results}

From a consecutive series of 36 patients with complex coronary lesions using the ACC/AHA score (19 type B, 17 type C) which 2 had a PCI of 2 vessels, 23 patients $(63.9 \%)$ had stable angina and 13 unstable angina. 36 of them had successful PCI (28 men), 21 patients (58.3\%) had troponin I elevation $(>0.04 \mathrm{ug} / \mathrm{l})$ post PCI of which 6 had unstable angina. Thirty four patients had a followup scan. Two patients had an unsuccessful second CMR scan due to claustrophobia. Three patients with atypical LGE pattern and troponin I elevation were excluded. All patients $(\mathrm{n}=19,51 \%)$ with troponin $(+)$ had more LGE in the post PCI scan than at baseline value (8 type M lesion, and 11 type $\mathrm{H}$ lesion). In the troponin (-) group there was no increase in LGE in the post PCI scan. There was a correlation between troponin elevation, severity of the lesion and the amount of new infarction as determined by LGE $(r=0.84)$.

\section{Conclusion}

Little is known about distal embolisation in complex coronary lesions. CMR is a useful tool, allowing non-invasive, rapid and accurate quantification of myocardial 
fibrosis without ionizing radiation. This study demonstrates the value of CMR in identifying potential consequences of periprocedural myocardial necrosis after PCI in complex coronary lesion in stable and unstable angina. Lesion complexity could be useful to predict myocardial damage post PCI in term of troponin rise and LGE.

Publish with Bio Med Central and every scientist can read your work free of charge

"BioMed Central will be the most significant development for disseminating the results of biomedical research in our lifetime. " Sir Paul Nurse, Cancer Research UK

Your research papers will be:

- available free of charge to the entire biomedical community

- peer reviewed and published immediately upon acceptance

- cited in PubMed and archived on PubMed Central

- yours - you keep the copyright

Submit your manuscript here:

http://www.biomedcentral.com/info/publishing_adv.asp 